\title{
1. Introduction: the absence of public interest
}

The recent uprisings in the Middle East have confirmed that autocratic forms of capitalism are, in the long term, not sustainable. An economy dominated by an elite few, with growing income inequalities and no sense of hope for the multitudes, turn protests into revolution. In the advanced economies since the mid-1980s there have been major shifts in the distribution of incomes towards the top 1 per cent of earners, while for the majority of people disposable income has stagnated. The concentration of incomes has produced distortions in the policy process and has also distorted democracy, with those on high incomes through political contributions and the ability to access the policy makers shaping and defining policy choices to reflect particular narrow vested interests, thus undermining the concept of the public interest.

The financial crisis of 2007 has confirmed the absence of a public interest at a number of levels. Firstly, it can no longer be assumed that policy makers seek election as a public service. Money in politics, financial contributions to key policy makers and political parties, together with the presence of strong lobbying at the stage of policy formulation, means that policy is often being shaped and defined to serve particular narrow vested interests as opposed to the public interest. Secondly, regulators who have the role of being the guardians of the public interest undermined their own status as gatekeepers. The Credit Rating Agencies (CRAs) designated as national regulators and trusted with the role of rating securities, undermined their role because of a conflict of interests between the issuer pay models and the ethics of their analysts. The CRAs downgraded $\$ 4.3$ trillion worth of securities from triple-A to below investment grade. The CRAs contributed to the financial crisis by rating multiples of asset based securities as triple-A. Thirdly, banking institutions sold securities to investors while at the same time the financial entities were themselves taking out insurance that these same securities would default.

The financial crisis points to a model of multiple interests and fragmentation, a framework that explores conflicts of interests and contestability over resources and who gets what explains the causes and consequences of the present recession. The processes of securitization and 
the growth of over-the-counter derivatives generated fees for the financial sector. Brokers, lawyers and issuers of securities all gained fees and high levels of compensation without thinking of the long-term consequences. Monopolies and asymmetries of knowledge reflected issues of power and influence.

Power and influence are not static. Between 1950 and 1974 labour movements were in ascendance because of full employment and increases in social provision. There was a narrowing of income inequalities. The period after 1979 represents a shift of influence towards high income earners and concentrations of incomes towards the top 1 per cent of earners with 99 per cent of the population receiving income increases of 0.6 per cent per annum. Since 1980 the top 1 per cent of earners have appropriated 65 per cent of GDP growth (Stiglitz 2010)

The recession of 2007 has to be located in social structures of growing income inequalities, with households exchanging equities in their homes for higher mortgages to compensate for stagnant incomes. Households were able to purchase consumer goods using their homes as an ATM machine. Power and influence in the shaping and making of policy generated a deregulated financial sector, while the ideology of free markets that dominated the thinking of institutions legitimized growing inequalities and unemployment as being the natural outcomes of markets.

The growth of income inequalities during the past three decades and the concentration of income within the top 1 per cent of earners have created a process for increased lobbying and political contributions to policy makers. Money in politics 'pollutes' the regulatory system (Ferguson and Johnson 2010). The concentration of power in the financial markets, where three banks in the UK have assets worth three times UK GDP (Haldane 2010) and five banks in the USA have assets equivalent to 65 per cent of US GDP (Johnson 2009), means that the financial sector plays an increasingly dominant part in the domestic economy. In the USA and the UK the financial sector has grown from 15 per cent to 40 per cent of corporate profits and as a ratio of GDP expanded from 5 to 9 per cent during the period 1990-2007.

The title of this book is The Politics of Recession. Implicit in that title are two related arguments. First, the approach challenges the argument that recessions are inevitable; that they are inescapable and somehow an inherent part of the market economy. Embedded within the thesis of inevitability runs the theme that recessions are exogenous and that they are experienced as an external event, where the role of government is limited to providing a series of policy initiatives to regenerate stability and economic prosperity. Attempts to regulate financial markets always represent fighting the last war because regulators can only catch a glimpse 
of rapid change. Secondly, the discourse of policy responses embeds the perspective of policy design serving the public interest, that in the context of austerity there has to be equal sacrifice and the recession is described as being a shared experience. However, recessions are political in the sense that these events are not shared experiences. They do not become part of a collective memory or shared culture or history. Recessions create winners and losers. The politics of recession therefore points to the view that recessions are not inevitable and they represent the outcomes of the policy process. Recessions are therefore not an exogenous event but are endogenous, and the study of recessions must therefore involve the study of the policy processes that contribute to them.

On her visit to the LSE in 2010 Queen Elizabeth II was not completely right to enquire with economists as to why they had been unable to predict the financial meltdown, since that question implied that the crisis was the result of the failure of economic models to predict the recession. However, the crisis was also a crisis of politics, of political institutions and social structures that reflected issues of power, influence and ideologies. Political scientists in their studies of the institutions of government and how these entities were guided by a liberal market philosophy did not make recommendations on the possibility that deregulated regulators were also contributing to the financial crisis. Equally, students of politics have been aware of the role of money in politics and how interest groups in finance were shaping the policy process that undermined regulatory processes. Money is increasingly influencing the policy process. Financial deregulation reflected the relationship between economic theories that pointed to liberalization of financial markets and the finance industry that benefitted from the process of deregulation.

During the years of the Great Depression of 1929, UK unemployment rates reached 25 per cent of the labour force. However, the experience of high unemployment was mainly concentrated in the traditional staple industries of coal mining, textiles and ship building. The new consumer goods industries of white goods, chemicals, car making and aeroplane manufacturing were thriving in the new industrial landscapes of the Midlands and the South of England. Keynes in making his case to the MacMillan Committee pointed out that governments, through a series of infrastructure projects, could reduce unemployment by 500,000 in the context of unemployment of 1.4 million. The cost of his programme was around $£ 100$ million, approximately 2 per cent of GDP. Skidelsky and Kennedy (2010) argued that Keynes was 'kicking up a fuss' against the orthodoxy of classical economics thinking that had dominated the Treasury view for the previous 200 years.

The Thatcher government policy choice to deal with inflation through 
high interest rates and reductions in public expenditure contributed to the recession of 1981 which resulted in a sharp rise in unemployment to over 3 million. At the time Lord Kaldor pointed out that any government could reduce inflation to zero by increasing unemployment (Kaldor 1980) The unemployment rate was explained away as being a labour market shakeout in the over manned nationalized industries. Between 1979 and 1996 the UK lost some 2.5 million jobs in manufacturing. In addition manufacturing output as a ratio of GDP also declined from 23 per cent to 18 per cent. Throughout the years of the Thatcher government, unemployment remained at around 2 million. This has to be compared with the period 1950-1970 when the unemployment rate averaged 250,000.

White (2010) has located the present financial crisis within two explanatory perspectives. These he called broadly 'the school of what is different' and 'the school of what is the same'. White suggested that the explanations that fall within 'the school of what is different' provided a comfort zone for policy makers because they could focus on financial innovations including residential mortgage backed securities (RMBS), CDOs and CDSs and look for ways in which these instruments can be reformed. Policy makers are at present debating on how to make the over-the-counter (OTC) derivatives safer on trading platforms and through central clearing, arguing that the problem with these instruments was opaqueness and lack of transparency. Within this category it is also observed that investment banks became too reliant on REPO markets and short-term lending so the argument is for increased capital requirements and better liquidity:

The 'school of what is different' focuses on the developments in financial markets that were new this time around. Such innovations as CDSs, structured products, SIVs and conduits, extensions of the originate to distribute model and the role of rating agencies, would all become centers of attention. This school of thought is relatively comforting to all those involved in the governance of the economic and financial system. New developments always have unanticipated side effects, and it would be unrealistic to expect those in charge to anticipate all of them in advance. (White 2010, p. 3)

Explanations that fall within the category 'what is the same' draw parallels with other financial crises and the history of global financial crises, pointing out that these crises have patterns of repetition in that they tend to start off in the financial sector and they usually include high levels of leverage by banks, stock markets and housing bubbles. They also point to the role of government, which has been to recapitalize financial markets, stabilize the economy and return to normality:

The school of 'what is the same' begins by noting that boom-bust cycles have been characteristic of liberalized economic and financial systems from time 
immemorial. Moreover, while each one is different ... in fundamental ways they all look the same. What is less 'comforting' about this school of thought is that it charges all those responsible for the governance of the economic and financial system with having missed obvious historical parallels. (White 2010, p. 3)

The IMF (2008) has catalogued 122 recessions in the world economy since World War II. The UK has experienced seven recessions since 1948 and the USA eight recessions during the same period. In the majority of cases the causes of recession have started in the financial sector with bubbles emerging in asset prices and in housing. Minsky (1976) and Kindleberger and Aliber (2005) have both provided explanatory framework for understanding bubbles and recessions.

Minsky (1976) has provided a cyclical explanation to explore the relationship between the previous recession and a subsequent climate of stability which then results in the fading of previous memories and which in turn leads to complacency about the past, euphoria about the future and then back to instability:

As the subjective repercussions of the debt-deflation wear off, as disinvestment occurs, and as financial positions are rebuilt during the stagnant phase, a recovery and expansion begins. Such a recovery starts with the strong memories of the penalty extracted because of exposed liability positions during the debtdeflation ... However, success breeds daring, and over time the memory of the past disaster is eroded. Stability is destabilizing in that more adventuresome financing of investment pays off ... Thus an expansion will, at an accelerating rate, feed into the boom. (Minsky 1976, p. 125)

The financial crisis that started in 2007 continues to be an economic, a political and a social crisis. The increases in unemployment in the UK and the USA represent economic, political and social challenges. The crisis in public finances and the reductions in public expenditure on health, social security and housing will impact those who had nothing to do with the causes of the crisis. Whereas public finance looked to be in good shape prior to 2007, since the bubble burst the sudden sharp falls in revenues to the government together with the shrinkage in GDP have created structural deficits in the public finances. In addition, the crisis in finance has also provided the opportunity for governments to redefine the boundaries between public and private provision. The UK coalition government strategy to reduce public expenditure by $£ 82$ billion by the end of the Parliament is founded on the argument that the public sector is crowding out the private sector and that a more vigorous, entrepreneurial and deregulated private sector will generate future economic prosperity.

The institutions of government are guided by philosophies and ideas 
that shape policy frameworks (Turner 2010). Policy practitioners develop relationships with theorists who provide ideas and ideals. Policy theorists have the ideas and but not the power to turn their ideas into policy. Policy practitioners are highly immersed in the policy process and seek the ideas that help policy making. Ideology plays a role in providing a framework of how to think about a problem. The 'approach' of free markets provide easy and ready to use tools for policy makers. Ideology therefore plays a role within institutions. Government organizations are not empty vessels they are guided by ideas and ideals.

For it is striking in the pre-crisis years how dominant and how overconfident, at least in the arena of financial economics, was a simplified version of equilibrium theory which saw market completion as the cure to all problems . . . Institutions such as the IMF, in its Global Financial Stability Reviews, set out a confident story of a self-equilibrating system. Thus, for instance, the April 2006 GFSR, only 18 months before the crisis broke, recorded that: 'There is a growing recognition that the dispersion of credit risks to a broader and more diverse group of investors ... has helped make the banking and wider financial system more resilient. The improved reliance may be seen in fewer bank failures and more consistent credit provision.' (Turner 2010, p. 4)

During that same speech Turner (2010) went on to argue that when he became the chair of the FSA he felt that he had become the high priest of the free market ideology that guided the FSA. The role of the FSA, as was made clear in policy statements, was to provide policy guidelines that ensured better working of the market. The FSA was not able to evaluate whether all financial instruments were socially relevant but only had to ensure that those instruments were transparent and accountable. The FSA accepted the concept of risk dispersion as generated by securitization and that the process of securitization was facilitating the process of market completion. Rational expectations and efficient markets theories provide the tools of analysis and were therefore part of the DNA at the FSA. Turner suggests these were the guidelines that also influenced the policy thinking within the IMF, where even in April 2007 the IMF was able to argue that securitization was contributing to market completion:

And in regulators such as the FSA, the assumption[s] that financial innovation and increased market liquidity were valuable because they complete markets and improve price discovery were not just accepted, they were part of the institutional DNA, part of the belief system. The belief system did not, of course, exclude the possibility of market intervention. But it did determine assumptions about the appropriate nature and limits of intervention. And here, I suspect, lies the greatest challenge for new economic thinking. For while the simplified pre-crisis conventional wisdom appeared to provide a complete set of answers resting on a unified intellectual system and methodology, really good economic 
thinking will provide multiple partial insights, based on varied analytical approaches. (Turner 2010, p. 9)

In the aftermath of the Great Depression and in response to the Pecora Hearings Senator Glass and Congressman Steagill were able to push through the so-called Glass-Steagill Banking Act of 1933 (Perino 2010). The provisions put in place the Federal Deposit Insurance Corporation (FDIC) to provide safeguards for individual savers and their deposits with the commercial banks and to prevent future bank runs. The period 1940 to 1980 became known as the Quiet Period for the financial sector (Gorton 2009). The repeal of Glass-Steagill in 1999 removed the divide between commercial and investment banks. The Quiet Period of banking had also become associated with a sort of complacency, the run on the banks was now past history. Commercial banks put policy makers under pressure to remove their restrictions and allow them to compete in the world of investment banking. The so-called shadow banking sector had grown to a $\$ 8$ trillion business which was now the same size as the regulated commercial sector. The difference was that commercial banks still had the deposits of individual savers as part of their assets. The investment banks had to rely on mutual funds to provide short-term overnight funding. The investment banks had to post collateral and mark their assets to market. Commercial banks could point to the fact that their assets were long-term assets and not prone to mark to market fluctuations.

Soon after Glass-Steagill was repealed the US Congress also passed the Commodity Futures Modernization Act (CFMA) of 2000, facilitating a framework for all OTC derivatives to be traded in non-regulated markets. The legislators passed provisions so that the OTC market was outside the jurisdiction of state regulators. The OTC derivatives market grew to a notional amount of $\$ 640$ trillion during the period 2000-2007, while the CDS market expanded to \$65 trillion(BIS Report 2009; Financial Times 17 March 2011). This growth has to be put in the context of global GDP of $\$ 65$ trillion, so that the OTC market in 2007 was 10 times the size of global income and the CDS market five times as big as the US economy (FCIC 2011).

Alan Greenspan's ideological commitment to free unfettered markets had a major influence on the thinking of the Federal Reserve. President Reagan had asked Greenspan to replace the outgoing Chairman Paul Volcker because Volcker was described as being a pragmatist and not committed to the deregulation of financial markets. By contrast, Greenspan was committed to the concept of free markets. Reflecting on the role of derivatives in the US economy, Alan Greenspan, as Chairman of the Federal Reserve at a conference organized by Futures Industry Association in March 1999, was able to argue that: 
By far the most significant event in finance during the past decade has been the extraordinary development and expansion of financial derivatives ... The fact that OTC markets function quite effectively without the benefits of [CFTC Regulation] provide a strong argument for development of a less burdensome regime for exchange trade financial derivatives. (quoted in FCIC 2011, p. 48)

On 23 October 2008, when over 90 per cent of asset backed securities previously rated as triple-A were downgraded to below investment grade Alan Greenspan provided testimony to the Oversight and Government Reform Committee. In his testimony Greenspan admitted that in 1999 he had made a mistake in his assumptions about markets and his longheld views that financial market participants would regulate themselves because of self-interest and that this was always preferable to government intervention:

I made a mistake in presuming that the self interest of organizations, specifically banks and others, were such that they best capable of protecting their own shareholders and their equity in the firm.... So the problem here is something which looked to be a very solid edifice, and indeed a critical pillar to market competition and freedom markets. did break down ... (quoted in Wessel 2010, pp. 65-6)

To which, Henry Waxman the Chairman of the committee responded:

'In other words you found that your view of the world, your ideology was not right. It was not working.'

'Precisely,' Greenspan replied. 'That's precisely the reason I was shocked because I had been going for forty years or more with considerable evidence that it was working exceptionally well ... ' (Wessel 2010, p. 66)

The financial crisis was also a crisis of economic ideas at both the intellectual and at the practical level. Economic models founded on the concept of rational individualism and the representative agent as developed by the Rational Expectations School and the Efficient Market Theorists had become the conventional wisdom within key financial institutions including central banks, but also global institutions such as the IMF (Turner 2010). The concepts of rationality and efficient markets, though both highly contestable concepts, became the essential building blocks in the modelling of the financial sector. The theory of rationality was an important pillar in model building because it assumed that all humans in aggregate behaved in a similar way, in that rational agents would recognize that markets were outside the normal range and would bring them back within the accepted range. This was the idea of a random walk of prices fluctuating on Wall Street representing a diversity of views and yet within that diversity prices would always remain close to the intrinsic value of that bond. 
Competition between market participants ensured that stock prices moved around their intrinsic values. The increase in house prices between 1997 and 2007 reflected the intrinsic value of housing. Housing was therefore not over priced but reflected the pressures of demand, of high wages, of limited land spaces and growing demographic pressures. Households behaved rationally in exchanging their 30-year fixed rate mortgages for adjustable rate mortgages that reflected changing market conditions; brokers selling housing with high sub-prime mortgages behaved rationally in extracting higher fees; bankers securitizing mortgages behaved rationally. Stock prices and forward options were all calculated on the basis of rational agents making predictable decisions to buy or sell assets on the basis of expected future dividends earnings. The Black Scholes model of option pricing became the yardstick of calculating stock pricing. The OTC derivatives market developed on the assumptions established by the rational expectations hypothesis $(\mathrm{REH})$ and the efficient markets hypothesis (EMH). The recent work by Colander (2009) and Lawson (2010) has criticized the models generated by Fama and Black and Scholes, firstly because of the unrealistic assumptions of the models and also the failure of these economists to point to the limitations of their models, even as these models became the basic tools of analysis in financial markets:

Many of the financial economists who developed the theoretical models upon which the modern financial structure is built were well aware of the strong and highly unrealistic restrictions imposed on their models to assure stability. Yet, financial economists gave little warning to the public about the fragility of their models; even as they saw individuals and businesses build a financial system based on their work. There are a number of possible explanations for this failure to warn the public. One is a 'lack of understanding' explanation - the researchers did not know the models were fragile. We find this explanation highly unlikely; financial engineers are extremely bright, and it is almost inconceivable that such bright individuals did not understand the limitations of the models. A second, more likely, explanation is that they did not consider it their job to warn the public. If that is the cause of their failure, we believe that it involves a misunderstanding of the role of the economist, and involves an ethical breakdown. In our view, economists, as with all scientists, have an ethical responsibility to communicate the limitations of their models and the potential misuses of their research. (Colander et al. 2008, pp. 3-4, original emphasis)

Economics had to be mathematical and publication in economic journals depended on the elegance of the mathematics rather on how well the model explained reality. Lawson (2010) has suggested that in explaining social material it is not always appropriate to use mathematical models. Social material cannot always be explained through mathematical models. You cannot use a hammer to measure a piece of glass or a violin bow to beat the drum in an orchestra. Each tool has a specific context. 
Like all tools they are appropriate to some uses and conditions and not to others. Though a hammer has various uses it is not particularly relevant to cutting the grass. I want to suggest that mathematical methods of the sort economists typically employ may not be particularly, or very often, well-suited for the illumination of social material, given the nature of the latter. The reasonable way forward, I thus argue, is explicitly to design explanatory approaches to be appropriate to the sorts of contexts and materials with which economists must actually deal. (Lawson 2010, p. 8)

Economists cannot repeat what happens in a physics laboratory that seeks to isolate both the intrinsic and extrinsic aspects of the observed variable. Variables used in economic models are assumed to be independent of each other, and it is also assumed that, through regression analysis, the weighting and explanatory potential of each separate variable can be measured accurately. Each variable is measured in isolation, as in physics. However, laboratory type closures are rare events in the social context:

Instead of existing in isolation, almost all social phenomena are in fact constituted in relation to each other. It is easy enough in modern capitalism to see the internal relationality of markets and money and firms and governments and households, etc; all depend on and presuppose each other. It would be futile and meaningless to seek to isolate any one from the influence of the others. But human individuals as social beings are likewise formed in relation to others. All slot into positions, where all positions are constituted in relation to other positions. Thus employer and employee presuppose each other, as do teacher and student, landlord/lady and tenant, parent and child, gendered man and woman, and so on. We all slot into, and are molded through the occupancy of, a multitude of such positions, deriving real interests from them, and drawing upon whatever powers or rights and obligations are associated with those positions. So social reality is an interdependent network, it is an internally related totality, not a set of phenomena each existing in relative isolation. (Lawson 2010, p. 8)

Economic theory is not neutral. Those who construct economic models make assumptions on a set of held beliefs about how economies work. The assumption that markets are neutral and are Pareto efficient, meaning that any attempt to redistribute income and make some better off will make some worse off, is in itself ideological. Market liberalism expunges context. The rational individual has no history, no place or culture. Data carries no time break, no possibility of changes of government, of changes in institutions, or reforms that might influence or contaminate the data. Data speaks for itself and does not need to be located in histories. In the rational deductive model either the theory comes first and then the data is squeezed to fit the theory, or the data is allowed to speak for itself but only within the frameworks of statistical analysis.

The discourses of neutral markets and capitalism as starting points are both embedded in ideology (Foley 2010). Friedman and Hayek are 
both good examples of having an ideology and using their ideology as an economic argument. Hayek's Road to Serfdom and Friedman's Free to Choose were both political arguments advocating an unfettered market economy. Keynes was equally being political when he argued that his main concern was full employment and that government should intervene, even through the process of socializing investment, to ensure that investment matched savings. Once the threat of unemployment was removed as a market discipline it was therefore likely that this would alter the relationships between capital and labour (Foley 2010). The debate between Keynesians and market liberals is therefore implicitly a debate about the distribution of income and about power. The argument of the neutral market shifts the power towards increased income inequality. The concern about full employment shifts the focus towards government and income redistribution Markets are not neutral they are social constructs.

Since the time of Adam Smith, his Invisible Hand has become the cliché metaphor for the stability of markets. The Hand 'guides' prices and outputs into equilibrium. Market fundamentalist (or laissez faire) doctrines presume that the economy is structured in such manner that this is always true. But the structure within which market interactions work themselves out is a creation of lawyers and politicians and, as all human creations, comes with no guarantee of serving us well for all time. (Leijonhufvud 2010, p. 1)

According to market fundamentalists the cause of the financial crisis was the government. Taylor (2010) put the blame on the Federal Reserve's loose monetary policy of low interest rates which eventually fed into the housing bubble, while Wallison (2011) connected the crisis with government housing policy encouraging home ownership among people who were a high credit risk.

Equally, economists who start from a Keynesian perspective, advocating full employment, are ideological in the sense that they see that we live in capitalist economy as opposed to the market economy and capitalism creates inequality. Although there are many variants of Keynesian thinking, Keynesians would point to concepts introduced by Keynes which a made departure from classical thinking. Keynes introduced the concepts of uncertainty as opposed to risk, the concept of animal spirits and market sentiment. Keynesians put an emphasis on the context of institutions and conventions that create a framework for certainty.

\section{THE STRUCTURE OF THE BOOK}

Chapter 2 deals with the anatomy of the present recession. The focus is the dynamics of house prices and the growing derivatives markets. The 
sub-prime mortgages represented a trigger effect and the chapter shows that attempts to put the blame on the housing bubble would be misleading. While home ownership did increase from 64 to 69 per cent in the USA, home ownership remained stable in the UK, Spain and Ireland, and yet in each of these countries there was a housing price bubble similar to that of the USA. Different housing policies with different structures of housing subsidies still ended up with rapid increases in house prices. The question is, therefore, why was there a global increase in house prices and why were property prices outstripping growth in disposable income. Some commentators in the USA have blamed the Clinton and Bush administration for putting pressures on the CRAs to increase home ownership among communities with high risks of default. There is no evidence that the CRAs actually downgraded their standards. Equally, the evidence shows that US households remortgaged about $\$ 2.3$ trillion worth of housing assets. This would suggest that existing home owners were converting their equities into liquid cash that allowed them to increase personal consumption. The default in housing estimated at a maximum of $\$ 1$ trillion has to be put in the context that some investment banks are involved in transactions worth $\$ 1$ trillion a day. So $\$ 1$ trillion of defaulting mortgages could have been absorbed within a global economy worth about $\$ 65$ trillion. The housing bubble should not have resulted in a global financial crisis. Housing was a trigger effect compared to issues of structural fragilities of financial markets. The breakdown in the historical correlation between house prices and disposable incomes shows that while house prices were for long periods approximately 3.5 times disposable incomes, after 1997 this had increased to 4.5 times disposable incomes. The breakdown between house prices and incomes suggested that the increases in house prices were not sustainable in the long term.

Chapter 3 is a review of various explanations and locates these explanations as a series of contestable issues. The first area of contestability is located in the role of government and the question of whether governments contributed to the financial crisis or whether the response of the government did actually stabilize financial markets and thus avoided a depression similar to the Great Depression of 1929. Market fundamentalists have suggested that governments contributed to the crisis through a loose monetary policy - a monetary glut - that resulted in low interests rates which in turn contributed to the housing boom. Pragmatists represented the policy makers who had to deal with the crisis as it was unfolding and did not have the benefit of time or hindsight. While the policy responses were piecemeal and disjointed, they did stabilize the financial markets and avoided a major collapse in the wider economy. The second area of contestability relates to issues of ideas and ideals. Explanations in this category included 
structuralists who sought to locate the recession within social structures in what Rajan (2010) called fault lines. Institutionalists analysed the process of deregulation and how the climate of deregulation had put handcuffs on regulators and created a climate of reluctance to regulate.

Chapter 4 is concerned with the OTC derivatives markets, the process of securitization and the question whether derivatives did contribute to the financial crisis? The central argument of the chapter is the lack of transparency in the OTC market; the opaqueness and complexity of instruments created uncertainty. The interconnected process meant that buyers and sellers of derivatives could not be sure whether counter parties could meet their obligations. The instruments created resulted in greater uncertainty so that when some mortgage backed securities (MBS) started to default with no clear connections of counter party risks, a number of mutual funds that had previously accepted MBS as collateral were now asking for more collateral and higher haircuts which eventually led to the collapse of Bear Sterns. The near collapse of AIG showed the CDS market was not a conventional form of insurance. AIG was not posting daily collateral for the selling of CDS. AIG had insured $\$ 80$ billion of CDS for a premium of $\$ 8$ billion. When Goldman Sachs asked AIG to meet the CDS exposure of $\$ 1.8$ billion AIG disputed the claim. There were no transactions at the time of CDS bonds. The market was frozen and therefore the prices were being determined through mathematical models. Marking to market was highly removed from statutory insurance. The posting of collateral would have provided signals of the real costs of insurance, but not trading derivatives on exchanges and clearing platforms created arbitrary prices that were disputed between counter parties. The near collapse of Bear Stearns, the rescue of AIG and the bankruptcy of Lehman Brothers altered the landscapes of financial markets.

Chapter 5 explores the credit rating agencies' issuer pay business models and how this connected with the financial crisis. The CRAs moved to the issuer pay model during the 1970s. The three major CRAs - Moody's, Standard \& Poor's and Fitch Ratings - were defined as Nationally Recognized Statistical Rating Organizations (NRSRO) by the Securities and Exchange Commission during the 1990s. Regulators therefore used the ratings by the CRAs to approve the investment portfolio of pension fund municipalities and government. These entities were restricted to investing in only triple-A rated bonds. Investors assumed that the ratings given by the CRAs were accurate. Investors did not do their own due diligence. The securitization of mortgages proved a bonanza for the CRAs as their incomes increased from $\$ 3$ billion to $\$ 6$ billion a year. CEOs of the CRAs were receiving salaries similar to the CEOs of investment banks. The testimonies given by analysts at Moody's and Standard \& Poor's to 
various enquiries confirmed that there were major discrepancies between the ethics of the analysts and the business models of the CRA. The pressure on the analyst was to rate a bond even when they were unhappy with what was contained in a structured security. Analysts argued that they could not walk away from a rating. There was concern about the models being used and whether these were out of date. Analysts were questioned when they failed to rate an issue. Issuers complained to the CRAs if an analyst was proving too difficult and the analyst was removed from the issuing process. The term IBGYBG (I'll be gone, you'll be gone) was first used between an issuer and an analyst, the issuer was telling the analyst not to take the analysis too seriously since in the long term they would both be gone and at least for the moment it was better to improve on their compensation packages.

Chapter 6 deals with the economics and social issues created by Keynes and other Keynesians who believed that Keynes represented a departure from classical economics, and looks at what the nature of that break implied for economic policy making. Minsky (1976) has argued that attempts to synthesize Keynes are misleading, since concepts such as uncertainty, conventions, or animals spirits could not be located within market liberal thinking. The IS/LM model of Hicks and Hansen and the argument of sticky prices were not Keynesian arguments. Keynes provided a theory of capitalism and not of markets. Keynes was not dealing with market failure but a capitalism that was cyclical and therefore could not guarantee full employment.

Chapter 7 argues the case that the financial crisis needs to be located in processes of social structure, in issues of power and influence, growing income inequalities and the influence of ideology in the policy process. The study of structures of government provides a framework for analysing the relationships between policy makers, lobbyists and financial donations and how these processes shape and define policy making. The shift towards a deregulated environment in financial markets reflected two decades of attempts to repeal Glass-Steagill which was finally achieved in 1999. The shift towards a deregulated environment enabled the growth of the counter derivatives. Secondly the growth in income inequalities allowed for an increased concentration of income towards the top 1 per cent of earners which enabled the process for increases in financial donations for narrow vested interests. Ideology in terms of how economies work was dominated by the conventional wisdom outlined in rational expectations theory and efficient markets theories. These concepts dominated the thinking of institutions involved in the policy process.

Chapter 8 outlines a history of UK economic policy since 1945. It breaks the period into three phases. The Butskellite consensus between 
1945 and 1970 represented a dual commitment to full employment and increased public provision. Inflation was to be controlled through incomes policy, which therefore required compromises between government and the trade unions on price controls in exchange for trade union moderation on wages. This was a period of narrowing income inequalities with wages rising in line with increases in productivity. The second phase between 1970 and 1979 - included the Heath government followed by the Callaghan government. Ted Heath had promised a Quiet Revolution in 1970 on trade union reform and phasing out subsidies on the nationalized industries. The increase in unemployment to over 1 million resulted in a series of U-turns on public expenditure. The British public were not yet ready to accept high unemployment. The Labour Government of 1974 represented a watershed in the sense that with rising unemployment, the government reduced public expenditure, which effectively confirmed the break with Keynesian thinking. The third phase, starting in 1979, saw the Thatcher Revolution, and this chapter explains how economic policy since 1979 has changed the UK economic landscape. The decline in UK manufacturing, continuing high rates of unemployment, the retreat of trade union influence and shifts in income distribution towards the top 1 per cent of earners have all changed expectations of government.

Chapter 9 is a study of the Financial Crisis Inquiry Commission (FCIC) which was chaired by Phil Angelides and which eventually reported in January 2011. The chapter seeks to draw parallels with the Pecora Commission that had been established by President Hoover to investigate the Great Depression of 1929. Pecora was the chief counsel to the investigation and during 10 days of examination in January 1933 had provided the framework for the President Roosevelt series of financial reforms in 1933, including the Banking Act of 1933. The FCIC enquiry was the most detailed enquiry into understanding the financial crisis, lasting 12 months and involving 12 major public hearings with thousands of documents and a series of interviews accumulated by the commission. In the final report of January 2011 the commission report broke down between the six Democrat Commissioners signing the majority report, and the Republican Commissioners submitting two separate dissenting documents. The majority report pointed to the failures of deregulation in the derivatives markets, failures by regulators and credit rating agencies. The majority report pointed to the high-risk strategies adopted by investment banks, the system of compensation, and how structured products created incentives based on the short-term interests of mortgage brokers, lawyers and issuers of securities without thinking of the long-term implications.

Recessions produce different geographies of inequality. Policy choices are central to understanding how issues of power and influence become 
embedded in the policy process. The present financial crisis reflects a continuing shift of influence towards those at the very top of the income scale. During the past 30 years, wages for the majority of the population have remained relatively stagnant. Improvements in living standards can be explained through the increased participation of women in the labour market with husbands and wives now both working to sustain a certain living standard of living. Secondly the increases in house prices after 1990 provided households with the opportunity to improve their consumption by surrendering the savings in their homes to improve personal consumption.

\section{REFERENCES}

BIS (2009) Annual Report 2008/09. Basel: Bank for International Settlements.

Colander, D., H. Föllmer, M. Goldberg, A. Hass, K. Juselius, A. Kirman, T. Lux and B. Sloth (2008) 'The Financial Crisis and the Systemic Failure of Academic Economics', unpublished mimeo.

Colander, D., H. Föllmer, A. Hass, K. Juselius, A. Kirman, T. Lux and B. Sloth (2009) 'Mathematics, Methods, and Modern Economics', Real-world Economics Review, 50(8): 118-121.

FCIC (2011) The Financial Crisis Inquiry: Final Report. Washington, DC: U.S. Government Printing Office.

Ferguson, T. and R. Johnson (2010) 'When Wolves Cry "Wolf": Systematic Financial Crises and the Myth of the Danaid Jar', INET Inaugural Conference, April.

Foley, D. (2010) 'Mathematical Formalism and Political-Economic Content'. Available at: http://ineteconomics.org/video/conference-kings/mathematicalformalism-and-political-economic-content-duncan-foley

Friedman, M. and R. Friedman (1980) Free to Choose: A Personal Statement. London: Harcourt.

Gorton, G. (2009) 'Slapped in the Face by the Invisible Hand: Banking and the Panic of 2007', presentation for the Federal Reserve Bank of Atlanta's 2009 Financial Markets Conference: Financial Innovation and Crisis, 11-13 May.

Haldane, A.G. (2010) 'The Debt Overhang', speech given at a Professional Liverpool Dinner, 27 January.

Hayek, F. (1944) Road to Serfdom. London: Routledge.

IMF (2008) 'What Happens During Recessions, Crunches and Busts?', IMF Working Paper by S. Classens, M. Kose and M. Terrones, WP/08/274, Washington, DC.

Johnson, S. (2009) 'The Quiet Coup', The Atlantic Monthly, May.

Kaldor, (Lord) N. (1980) Memorandum on Monetary Policy. London: HMSO.

Kindleberger, C. and R. Aliber (2005) Manias, Panics and Crashes: A History of Financial Crisis. London: Palgrave Macmillan.

Lawson, T. (2010) 'Economics and Science', The Transatlantic: Journal of Economics and Philosophy, 1: 8-13. Available at: http://thetransatlantic. org/2010/03/10/economics-science/ 
Leijonhufvud, A. (2010) 'Instabilities', paper presented at the INET Conference, King's College, 8-11 April.

Minsky, H.P. (1976) John Maynard Keynes. London: McGraw Hill.

Perino, M. (2010) The Hellhound of Wall Street: How Ferdinand Pecora's Investigation of the Great Crash Forever Changed American Finance. New York: The Penguin Press.

Rajan, R. (2010) Fault Lines: How Hidden Fractures Still Threaten the World Economy. Oxford and Princeton, NJ: Princeton University Press.

Skidelsky, R. and M. Kennedy (2010) 'Future Generations Will Curse Us for Cutting in a Slump', The Financial Times, 27 July.

Stiglitz J (2010) Free Fall: America, Free markets and the Sinking of the World Economy. London: W.W. Norton and Company.

Taylor, J. (2010) 'The Financial Crisis and the Policy Responses: An Empirical Analysis of What Went Wrong', paper presented to the Financial Crisis Inquiry Commission, Washington, DC, 2 September.

Turner, A. (2010) 'Economics, conventional wisdom and public policy', Institute for New Economic Thinking Inaugural Conference, Cambridge, April.

Wallison, P. (2011) 'Dissenting Statement, Peter P. Wallison, 24 December 2010', The Financial Crisis Inquiry Report. New York: Public Affairs.

Wessel, D. (2010) In Fed We Trust: Ben Bernanke's War on the Great Panic. New York: Three Rivers Press.

White, W. (2010) 'Remarks by William White to be delivered at the INET Conference Session 1 "Anatomy of Crisis - the Living History of the Last Thirty Years: Economic Theory, Politics and Policy?"”, King's College, Cambridge, UK, 9 April. 